\title{
THE RELATIVE GROWTH RATES OF WHITE SPRUCE AND BALSAM FIR TREES IN THE PORT ARTHUR DISTRICT OF ONTARIO
}

\author{
By R. J. BURGAR ${ }^{1}$
}

Robert J. Burgar was born and educated in Toronto, Ontario. He received his B.SC.F. degree from the University of Toronto in 1954. Upon graduation he was employed by the J. J. McFadden Lumber Co. Since 1955 he has been employed by the Ontario Department of Lands and Forests, first as a Zone Forester in the Lake Simcoe District, later as an assistant nursery superintendent, forest unit manager, and presently as acting nursery superintendent in the Port Arthur District.

\section{ABSTRACT}

Height, diameter and age relationships of 482 white spruce and 692 balsam fir in the mixed wood cover type of the boreal forest in the Port Arthur District, Ontario, were examined to ascertain which of the two species produces the most wood volume in individual trees in a given period of time.

The study established that the merchantable wood volume production of the average white spruce tree is approximately $35 \%$ more at age $25,40 \%$ more at age 60 , and $110 \%$ more at age 90 than that of the average balsam fir at the same ages.

\section{INTRODUCTION}

To formulate reforestation plans that will encourage the proper species to make the most effective use of a site it is necessary to know the silvicultural characteristics of the trees involved. One of the important characteristics to be considered, when making reforestation plans, is the growth rate of species adaptable to the site for which the plans are being prepared.

Growth rate is usually considered in terms of height growth or diameter growth. However since volume growth rate, the combination of these two measurements, is a more useful indication of wood productivity it is this measurement that will be used to compare, in this paper, the relative growth rates of white spruce (Picea glauca (Moench.) Voss) and balsam fir (Abies balsamea (L) Mill) in northwestern Ontario's Port Arthur District.

\section{STUDY AREA}

The area of this study is confined to boreal forest mixed-wood and sprucefir cover types which occur in the Port Arthur District.

These two cover types contain white spruce, balsam fir, black spruce (Picea mariana Mill B.S.P.), jack pine (Pinus banksiana Lamb.), trembling aspen (Populus tremuloides Michx.), balsam poplar (Populus balsamifera L), and white birch (Betula papyrifera Marsh) in varying proportions with white spruce and balsam fir being the most important commercial species in these types. According to Rowe (1959) these types are confined, broadly speaking, to the deep, well-drained, fertile till deposits, loamy sands of river valleys,

\footnotetext{
${ }^{1}$ Acting nursery superintendent, Port Arthur District, Ontario Dept. of Lands and Forests, Fort William, Ont.
} 
and slopes to rivers or lakes. Due to the broken, rolling nature of the topography in this area these types are seldom found covering large areas but in total they occupy at least $34 \%$ of the productive forest land of the District (Anonymous, 1953).

Because the mixedwood and spruce-fir types contain the same species, occupy similar sites and follow the same regeneration patterns, they are considered as one type for the purpose of this study.

\section{NATURE OF STUDY}

Information on height, diameter and age used in this study was obtained from several governmental and industrial forest surveys conducted in the Port Arthur District.

Measurements for only those white spruce and balsam fir which occurred in the mixedwood and spruce-fir types were used in the study. The recorded measurements represent forest conditions in all parts of the study area except the extreme northwestern portion which is presently inaccessible. Growth rate differences attributable to minor site differences existing in various parts of the District are considered negligible for the purpose of this study. For that reason all the measurements are treated as though the trees utilize one site.

Using the height and diameter information a gross merchantable volume was calculated for each tree. The data for the individual trees, 692 balsam fir and 482 white spruce, were then separated into 10-year age classes by species. Averages of age, breast height diameter, height and volume for each ten year age class were then determined and are shown in Tables 1 and 2 . Height and diameter information are presented in the Tables to show the increasing tree sizes as age increases.

The fall in height and diameter beyond 110 years in. balsam fir is probably attributable to the small sample, which will not allow the establishment of reliable averages for the 111-120 and 121-130 age classes.

TABLE 1

White Spruce Average Age, Diameter, Height and Gross Merchantable Volume BY 10-Year Age Classes

\begin{tabular}{cccccc}
\hline $\begin{array}{c}\text { Age Class } \\
\text { (Years) }\end{array}$ & $\begin{array}{c}\text { No. of Sample } \\
\text { Trees }\end{array}$ & $\begin{array}{c}\text { Average } \\
\text { Age } \\
\text { (Years) }\end{array}$ & $\begin{array}{c}\text { Average } \\
\text { d.h.h. } \\
\text { (Inches) }\end{array}$ & $\begin{array}{c}\text { Average } \\
\text { Height } \\
\text { (Feet) }\end{array}$ & $\begin{array}{c}\text { Average Gross } \\
\text { Merch. Vol } \\
\text { (cu. ft.) }\end{array}$ \\
\hline $21-30$ & 8 & 27.4 & 6.2 & 32 & 3.36 \\
$31-40$ & 27 & 36.6 & 7.2 & 42 & 6.18 \\
$41-50$ & 63 & 45.9 & 8.3 & 48 & 9.45 \\
$51-60$ & 59 & 54.0 & 8.6 & 53 & 10.69 \\
$61-70$ & 62 & 65.5 & 8.9 & 52 & 13.53 \\
$71-80$ & 61 & 75.0 & 9.5 & 57 & 13.38 \\
$81-90$ & 46 & 86.4 & 10.5 & 64 & 19.35 \\
$91-100$ & 39 & 95.7 & 10.4 & 62 & 17.66 \\
$101-110$ & 40 & 105.1 & 11.4 & 68 & 24.19 \\
$111-120$ & 33 & 115.8 & 12.5 & 71 & 30.08 \\
$121-130$ & 20 & 127.2 & 14.2 & 77 & 37.74 \\
$131-140$ & 19 & 136.6 & 15.2 & 80 & 48.86 \\
$141-150$ & 5 & 144.8 & 16.0 & 79 & 50.6 \\
Total Trees-482 & & & & & \\
\hline
\end{tabular}


TABLE 2

Balsam Fir Average Age, Diameter, Height and Gross Merchantable Volume by 10 Year Age Classes

\begin{tabular}{cccccc}
\multicolumn{5}{c}{$\begin{array}{c}\text { Balsam Fir Average Age, Diameter, Height aNd Gross } \\
\text { Merchantable }\end{array}$} \\
$\begin{array}{cccccc}\text { Age Class } \\
\text { (Years) }\end{array}$ & $\begin{array}{c}\text { No. of Sample } \\
\text { Trees }\end{array}$ & $\begin{array}{c}\text { Average } \\
\text { Age } \\
\text { (Xears) }\end{array}$ & $\begin{array}{c}\text { Average } \\
\text { d.b.h. } \\
\text { (Inches) }\end{array}$ & $\begin{array}{c}\text { Average } \\
\text { Height } \\
\text { (Feet) }\end{array}$ & $\begin{array}{c}\text { Average Gross } \\
\text { Merch. Vol. } \\
\text { (co. ft.) }\end{array}$ \\
\hline $21-30$ & 25 & 26.4 & 5.2 & 32 & 2.5 \\
$31-40$ & 32 & 32.8 & 6.7 & 41 & 4.92 \\
$41-50$ & 74 & 45.4 & 7.3 & 49 & 6.84 \\
$51-60$ & 137 & 55.9 & 7.6 & 48 & 7.83 \\
$61-70$ & 153 & 65.4 & 7.6 & 53 & 7.95 \\
$71-80$ & 127 & 75.0 & 7.6 & 52 & 7.86 \\
$81-90$ & 66 & 84.9 & 8.3 & 55 & 9.76 \\
$91-100$ & 52 & 95.2 & 8.3 & 53 & 9.30 \\
$101-110$ & 15 & 104.8 & 8.1 & 57 & 9.36 \\
$111-120$ & 7 & 115.6 & 7.5 & 52 & 8.20 \\
$121-130$ & 4 & 123.5 & 6.3 & 44 & 4.45 \\
Total Trees-692 & & & & & \\
\hline
\end{tabular}

To this point, gross merchantable volume has been used as the criterion of growth but to present a more accurate picture, the decay factor should be taken into account. The pathological survey work of Morawski, Basham and Turner (1958) established that balsam fir loses more volume through disease and decay than does white spruce $(10.6 \%$ and $3.5 \%$ respectively at 90 years) and since this factor would further emphasize the margin of growth superiority of white spruce, this factor will not be expanded. Figure 1 therefore shows only gross merchantable volume.

\section{RESULTS}

Tables 1 and 2 show that balsam fir and white spruce grow, in height, at the same rate until age 70 at which point height growth of balsam fir is reduced considerably. However in the same period (age 21-70) white spruce averages considerably more diameter growth than balsam fir.

Since volume growth combines both height and diameter growth and is therefore the best indicator of overall tree growth, the volume figures are plotted against age at breast height in Figure 1 to show the volume growth rate of the two species. The curves in Figure 1 were balanced by Dwight's (1937) method.

Figure 1 shows that at age 25 white spruce produces approximately $35 \%$ more merchantable wood volume than balsam fir. This early difference increases until at age 90 , which is the commonly prescribed rotation age for both species, individual white spruces contain approximately twice the amount of wood that single balsam fir trees produce in the same period. It seems unlikely that this volume advantage of white spruce could be compensated by a greater number of balsam fir trees per acre.

\section{DISCUSSION}

Silvicultural aspects must be studied carefully to ensure that the species which constitute the regeneration will utilize the site most efficiently. While 
FIGURE I,

Grose merchantable wood valume, of oges $20-120$, produced by the overoge white spruce and the overoge balsom fir.

40

30
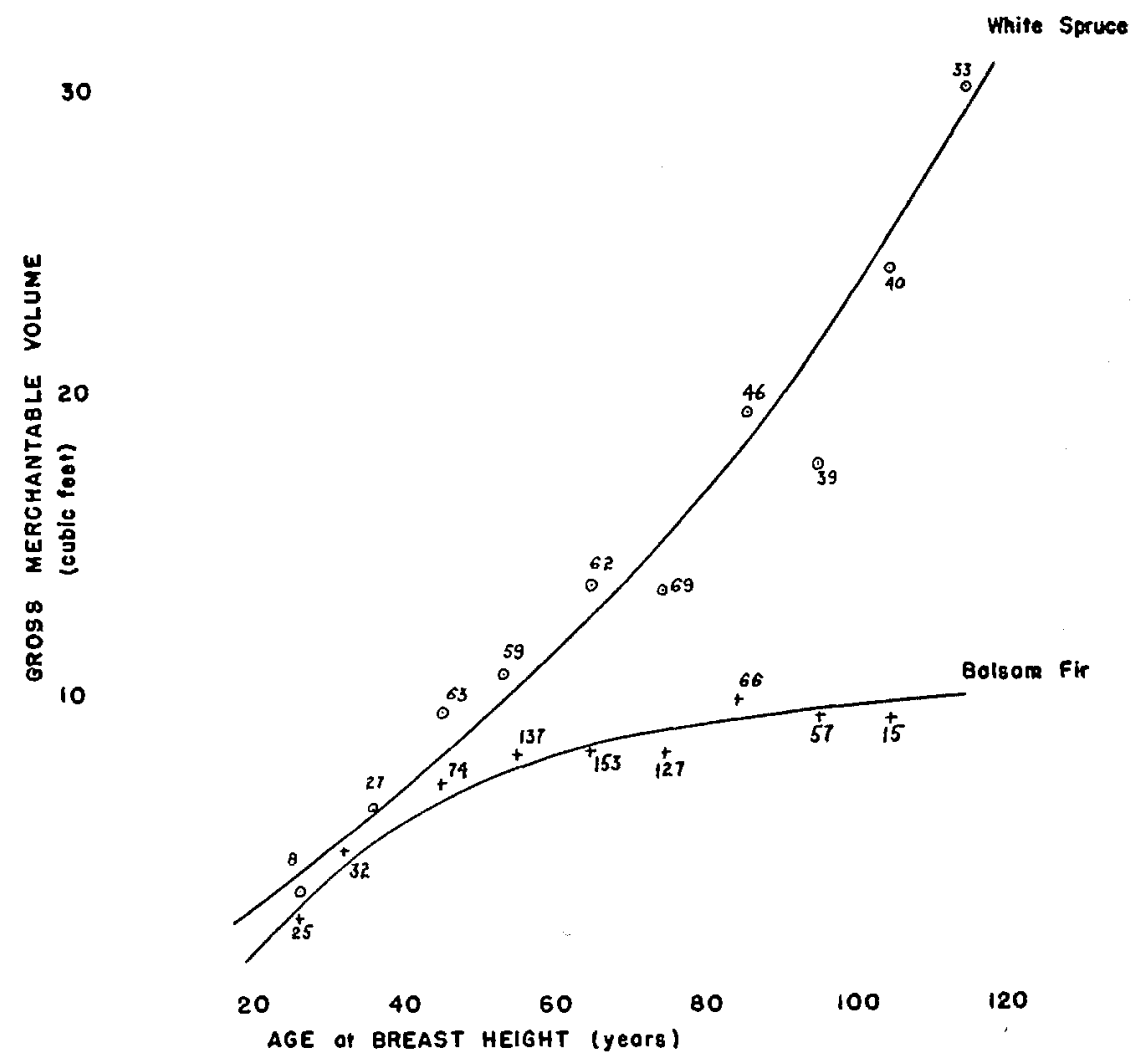

the author recognizes that financial considerations are of equal importance in the overall regeneration picture, he is convinced that the silvicultural problems concerning regeneration must be solved first in order to establish a firm foundation upon which to base financial decisions.

Several authors, Hosie (1953), Larsson and Lyon (1948), and Bonner and Sexsmith (1960) have established that following cutting and spruce budworm epidemics, the mixedwood and spruce-fir types in Northwestern Ontario are regenerating mainly to balsam fir. By some it is felt, primarily because balsam 
fir regeneration is obtained at no expense, that balsam fir is adequate to meet our future wood requirements and fulfill the objectives of sustained yield management. Others, who advocate obtaining a larger proportion of spruce, believe that there are many unnecessary dangers involved in allowing the trend towards a preponderance of balsam fir to continue.

In the author's opinion the size and the productive capacity of this forest area make extremely urgent the formulation and application of sound reforestation policies regarding white spruce and balsam fir in the mixedwood and spruce-fir types.

Elliott (1960) has shown that balsam fir suffers larger losses than white spruce as a result of spruce budworm epidemics. Furthermore, the utilization of balsam fir is restricted primarily to pulpwood whereas white spruce is useful for a wide variety of products such as pulpwood, lumber and piling. To partially offset some of these disadvantages, and in an attempt to rationalize the acceptance of extensive balsam fir regeneration, it is often claimed that balsam fir "grows faster" than white spruce.

The present study suggests that white spruce will produce more wood volume than balsam fir at any age and coupled with the other advantages of white spruce it seems logical that white spruce should be used to replace some of the balsam fir in mixedwood and spruce-fir types.

\section{CONCLUSIONS}

At any rotation age, and especially for products other than pulpwood, white spruce should be favoured over balsam fir.

This study has established that on an individual tree basis, white spruce will produce more wood volume in any given period of time than will balsam fir. The growth characteristics of these two species indicate quite strongly that white spruce should be encouraged to form a larger part of the next crop at the expense of balsam fir. In this way the quantity and quality of the wood yield of the mixedwood and spruce-fir forest lands can be increased significantly.

\section{ACKNOWLEDGEMENTS}

The co-operation of the Great Lakes Paper Company and the Ontario Department of Lands and Forests, Port Arthur, in supplying basic data for this study is gratefully acknowledged. The author wishes to thank N. F. Lyon, Research Forester, Ont. Dept. of Lands and Forests, Port Arthur, for his advice and comments concerning this paper.

\section{REFERENCES}

ANONYMOUS, 1953. Forest Resources Inventory Report No. 6, Ont. Dept. of Lands and Forests, Toronto, Ont., pp. 6, 11, 12, 22.

BONNER, E. and E. R. SEXSMITH, 1960. Ten years of Industrial Planting. Can. Pulp and Paper Assoc. Wood Review, Feb. 1960.

DWIGHT, T. W. 1937. Refinements in Plotting and Harmonizing Freehand Curves. For. Chron. 13 (2): $357-370$

ELLIOT'T, K. R. 1960. A History of Recent Infestations of the Spruce Budworm in Northwestern Ontario, and an Estimate of the Resultant Losses. For. Chron. 36 (1).

HOSIE, R. C. 1953. Forest Regeneration in Ontario. Univ. of Tor,, For. Bul. No. 2, Univ. Tor. Press.

(Continued on Page 223) 
TABLE 1

Dates When Terminal Shoots Reached 90 Per Cent of Their Growth

\begin{tabular}{|c|c|c|c|c|c|}
\hline Provenance & Block 1 & Block 2 & Block 3 & Block 4 & Average \\
\hline Sunbury Co., N.B. & July 15 & July $10^{1}$ & July 14 & July 10 & July 12 \\
\hline York Co., N.B. & July 14 & July 15 & July $11^{1}$ & July $10^{1}$ & July $12(+1 / 2)$ \\
\hline Saint John Co., N.B. & July 17 & July $\quad 9^{1}$ & July $9^{x}$ & July $8^{1}$ & July 11 \\
\hline Halifax Co., N.S. & July 14 & July 13 & July 16 & July $10^{1}$ & July 13 \\
\hline West Virginia & July 20 & July 30 & July 21 & July 18 & July 22 \\
\hline
\end{tabular}

TABLE 2

Dates When Terminal Growth Ended

\begin{tabular}{lllllll}
\hline \multicolumn{1}{c}{ Provenance } & Block 1 & \multicolumn{1}{c}{ Block 2 } & Block 3 & Block 4 & Average \\
\hline Sunbury Co., N.B. & July 27 & July 30 & July 30 & July 30 & July 29 \\
York Co., N.B. & July 30 & July 30 & July 27 & July 27 & July 28 (+1/2) \\
Saint John Co., N.B. Aug. 3 & July 24 & July 27 & July 30 & July 29 \\
Halifax Co., N.S. & July 27 & July 27 & Aug. 3 & Aug. 3 & July 30 (+1/2) \\
West Virginia & Aug. 6 & Aug. 17 & Aug. 6 & Aug. 14 & Aug. 11 \\
\hline
\end{tabular}

Discussion

The phenological findings described here parallel those reported by Santamour (1960), from a range-wide white pine provenance planting in New Jersey. There, bud swelling and shoot elongation started about the same time in all provenances; but active terminal growth continued two to three weeks longer in the southerly provenances than in the northerly. Nienstaedt (1958) obtained similar results with eastern hemlock in Wisconsin, with the addition that stock from southern seed sources suffered more frost damage than the northern material.

Because there are no real differences between the dates of initiation of new growth among the various provenances of red spruce tested, there should be no differences between their susceptibility to damage from late spring frosts. However, the delay of two weeks in completion of growth and ripening of terminal shoots on the West Virginia stock could make this race more liable to damage from early autumn frosts.

\section{REFERENCES}

NIENSTAEDT, Hans. 1958. Height growth is indicative of the relative frost resistance of hemlock seed sources. United States, Dept. Agriculture, Forest Service, Lake States For. Exp. Sta., Tech. Note No. 525.

SANTAMOUR, Frank S. Jr. 1960. Seasonal growth in white pine seedlings from different provenances. United States, Dept. Agriculture, Forest Service, Northeast For. Exp. Sta., For. Res. Note No. 105.

(Continued from Page 221)

LARSSON, H. C. and N. F. IYON, 1948. Forest Regeneration Survey on Cutover Spruce-Fir, Spruce and Pine Lands in the Midwestern and Western Regions. Ont. Dept. Lands and Forests Res. Div., Res. Pap. 17.

MORAWSKI, Z. J. R., BASHAM, J. T. and K. B. TURNER, 1958. A Survey of a Pathological Condition in the Forests of Ontario. Ont. Dept. Lands and Forests Rep. 25, pp. 19, 28.

ROWE, J. S. 1959. Forest Regions of Canada. Canada Dept. of Northern Affairs and National Resources Bul. 123, pp. 17-19. 